\title{
Financial Performance of Selected Regional Rural Banks in Jammu and Kashmir- An Empirical Study
}

\author{
Attaullah Niazi*, Prof. Nisar Ahmed Mulla** \\ *Attaullah Niazi, Ph.D. Research Scholar, Department of Commerce \& Management, MANUU, Hyderabad- \\ 500032, Email: attaullahnz@ gmail.com, Mobile: +91-9419100386. \\ ** Dr. Nisar Ahmed Mulla, Professor, Department of Commerce \& Management, MANUU, Hyderabad- \\ 500032, Email: drnimulla@gmail.com, Mobile: +91- 9490019183.
}

Article History: Received: 10 November 2020; Revised 12 January 2021 Accepted: 27 January 2021; Published online: 5 April 2021

\begin{abstract}
Regional Rural Banks(RRBs) have been formed to serve rural areas with banking and other financial Services. These institutions were brought in the public domain through an ordinance passed by the then President of India in September 1975, with the intent of providing banking and credit facilities for the agriculture and other rural section of the society across the nation. They are key financing institutions at rural levels that provides agriculture credit in rural areas. RRBs have more access to rural areas and play a key role in strengthening the agriculture sector \& rural development of India. The main objectives behind the formation of such type of vibrant institution in India was to established a link between the banks and rural households, especially in banking deprived areas. Moreover, to encourage rural savings, to generate employment opportunities, and to provide cheaper credit to the marginalised section in rural India.

Presently, the RRBs are under great pressure and going towards financial distress (As revealed from studies). In this paper, an attempt has been made to study the financial performance of Selected Regional Rural banks (RRBs) of J\&K by applying "CAMEL" Model approach. The finding of the study revealed that the performance of the J\&K Grameen Bank(JKGB) and Ellaquai Dehati Bank(EDB) is not up to the mark.
\end{abstract}

Keywords: Regional Rural Banks, Credit, Financial Distress, CAMEL, Marginalized section.

\section{INTRODUCTION}

Regional Rural banks(RRBs) in India was established in India on Gandhi Jayanti (2 October) in the year 1975, under the provisions of an Ordinance passed on 26th September, 1975 \& RRBs Act, 1976, on the recommendation of the Narsshimham committee during the tenure of Indira Gandhi's Government. To address the requirements and problems of rural households in India the Narshimham committee felt the need of regionally oriented rural banks in India, consequently, Five Regional Rural Banks(RRBs) were set up in 5 different States of India, i.e., in Rajasthan, West Bengal and Haryana with one bank each and two banks were given to Uttar Pradesh (UP) which were sponsored by different Indian commercial banks. 
Ensuring adequate institutional credit for agriculture and other rural sectors was the main objective behind the establishment of RRBs in India. Regional rural banks(RRBs) mobilise financial resources from rural \& semi urban areas \& grant loans and advances mostly to rural artisans, small and marginal farmers \& agricultural laborers.

\section{JAMMU \& KASHMIR GRAMEEN BANK(JKGB)}

$\mathrm{J} \& \mathrm{~K}$ Grameen Bank(JKGB) is a Jammu and Kashmir based rural bank sponsored by J\&K Bank which offers product and services such as Loans, Deposits, Current Accounts, Saving Accounts, Rupay Debit \& Rupay Kissan Cards and other financial services in the rural areas of J\&K. It was established on 30th June 2009 under RRBs Act, 1976 and functions in Thirteen districts of erstwhile state of Jammu and Kashmir, Now Union territory under Jammu and Kashmir reorganisation Act 2019.

JKGB have a wide network which consists Six Regional Offices 217 branches in J\&K and Ladakh, out of these 217 branches, 215 branches in the UT of Jammu \& Kashmir and two branches in Ladakh, that are engaged in providing all types of financial services in both the newly created Union Territories ${ }^{1}$.

\section{ELLAQUAI DEHATI BANK(EDB)}

Ellaquai Dehati Bank (EDB) is a RRB established on the 16th of July 1979 under the RRBs-Act 1976. Government of India, State bank of India \& Government of Jammu \& Kashmir are the joint owners of the Bank. The Bank has its presence in both the divisions of the Union Territory and has at present a network of 116 Branches and 3 extension counters spread across thirteen districts of the Union Territory (Srinagar, Budgam, Ganderbal, Anantnag, Pulwama, Shopian, Kulgam, Jammu, Udhampur, Reasi. Ramban, Doda, and Samba).

\section{REVIEW OF LITERATURE}

- NABARD (2020) in its report "An Overview of Financial Performance of RRBs" The finding of the study reveals that total Business of the RRBs as of 31 March 2020 stood at 7.77lakh crore. Regional rural banks, at an aggregated level, achieved a growth of 8.6\%. Advances, Deposits \& Net Loans of the institutions increased by $10.2 \%$ and 9.5\%, respectively. 17 out of the 45 RRBs had CRAR less than 9\%, and six RRBs had negative CRAR (\%). System-wide CRAR percentage (\%) of the banks deteriorated from $11.5 \%$ as of March 31, 2019, to $10.2 \%$ on 31 March 2020.

- Dr. Nagendra Kumar (2020) in his research article focused on the financial performance regional rural banks(RRBs) in India for Pre and post amalgamation period based on deposit and credit ratio. The study is concluded that there is no significant difference in deposit and credit ratio.

- S. Selvakumar D. Abima (2020) in his study focused on analysing the short-term \& long-term solvency and profitability to know the financial performance of Regional

\footnotetext{
${ }^{1}$ https://www.jkgb.in
} 
Rural Banks (RRBs). Researcher has selected Maharashtra Gramin Vikash Bank(MGVB), Assam Gramin Vikash Bank(AGVB) for the study. The study shows that all the 3 Gramin Vikash banks(GVB) (Maharashtra, Karnataka \& Assam) are performing well during the study period.

- Ahamed Lebbe Abdul Rauf (2016) in his study entitled "Towards increasing the Financial Performance an Application of CAMEL Model in Banking Sector in Sri Lanka" has focused on evaluating the comparative capability of performance of public and private banks of Srilanka. The study shows the sound Financial performance of private banks in all parameters of CAMEL as compare to public banks.

- Mohammed Mizanur Rahman \& Md. Tofael Hossain Majumder (2016) in their study on "A CAMEL Model Analysis of Selected Banks in Bangladesh" has selected 15 banks of Bangladesh to study their financial performance. The study is concluded by saying that EBL is performing well as per CAMEL Model analysis because of its sound financial performance in the Asset Quality, Capital Adequacy, Management \& Earnings Ability, and EIBBL is in the second position.

- Prashanth (2015) in his study on "Financial performance evaluation of Regional rural banks(RRBs) in Karnataka" in which he has focused on the regulatory framework of RRBs in India, Liquidity, Solvency and Profitability position of RRBs. The study is concluded by saying that deposit mobilization of Regional RRBs of Karnataka during the period shows the positive sign and the bank has used less amount of propitious funds and more amount of debt funds, working funds of the firm shows an increasing trend, branches are generating maximum profit.

- Mustafa Hassan Mohammad (2014) have Evaluated the Financial Performance of Erbil bank using Financial Ratios. The study shows that the return on assets (ROA) of the banks was negatively influenced by size of the bank, operational efficiency is negatively related to the return on assets(ROA) \& interest income shows negative relation with the operational efficiency.

- Alshiqi \& Hoti (2014) have studied the "Financial Performance of Kosovo's Banking system " during 2006 - 07 to 2011 - 12 by calculating Return on Investment through the CAMEL model approach. The study revealed that there is no significant difference in the overall performance of the banks and most of these banks were found with a healthy balance sheet.

- Kanika and Nancy (2013) in their research paper on "Financial Performance evaluation of regional rural banks (RRBs) in India" have focused on analysing the growth pattern \& financial soundness of RRBs in India. As per the results of the study, amalgamation and various other factors have a encouraging impact on the Financial Performance of RRBS.

- Kumar \& Sharma (2013) in their research article analysed the Financial performance of the top ten highest market capitalized banks by using the CAMEL model. The study has concluded by saying that in terms of capital-adequacy Kotak Mahindra Bank has the highest position followed by ICICI bank. State Bank of India has the highest Nonperforming Assets(NPA) level followed by Industrial Credit and Investment Corporation of India(ICICI) whereas, Punjab National Bank is highly managed, overall 
State Bank of India(SBI) is ranked as 1st followed by Punjab National Bank(PNB) \& Housing Development Finance Corporation(HDFC).

- Soni Kumar and Kapre Abhay (2012) in their study on "Financial Performance of Indian RRBs" during the period of 2006 - 07 to 2010 -11 have focused on key financial performance indicators like advances, Loan and number of bank branches. The study has concluded by saying that these performance indicators have a positive impact on the health of Regional Rural banks.

- Abhay Kapre \& Anil Kumar Soni (2012) in their study have analysed Performance of Regional Rural Banks(RRBs) in India". The study reveals that Owned funds have recorded a growth of 13\%, Deposits of RRBs increased from 14,5035 crores to $16,6232.34$ crores throughout the year, and registering a growth-rate of $14.60 \%$, Borrowings of RRBs is showing an increase of $41.10 \%$.

\section{NEED FOR THE STUDY}

The Regional rural banks(RRBs) were formed to serve the rural inhabitants of India, the majority, who were not having access to banking. There are many institutions set up by the State and Central Govt. and some in collaboration. The main objective of this institution is to serve the rural population. But how well have these banks performed because banking being an economic activity should be profitable These banks were set up not to make profits, but to survive, they should earn enough to meet their expenses.

This study compares the financial performance of JK-Grameen Bank(JKGB) and Ellaqui Dehati Bank(EDB), the prominent institutions that serve the rural population of Jammu and Kashmir.

\section{OBJECTIVES}

The Primary objectives of the study are follows:

1. To Evaluate the Financial Performance of Selected Regional Rural Bank (RRBs) using CAMEL-Model approach.

2. To compare the financial performance of these selected banks.

\section{RESEARCH METHODOLOGY}

This is a descriptive \& analytical study based on secondary data collected from annual "financial reports" of the selected banks. This study is based on J\&K Grameen Bank(JKGB) and Ellaqui Dehati Bank(EDB) for the period of 5 years (2015-16 to 2019-20).

\section{TOOLS OF ANALYSIS}

\section{CAMEL-Rating System}

CAMEL model approach was developed in the United States of America (USA) to describe the banks' overall performance. This model is applied to approximately Eight thousand institutions covering every credit union \& bank in the United States of America (USA) and now it is also being implemented by numerous banking supervisory regulators in other parts of the world. 
> CAMEL-Rating System (Components)

The banks are rated on the basis of camel

* C stand for capital adequacy.

* A stand for assets quality.

* M stand for management efficiency.

* E stand for Earnings quality, and

* L for Liquidity.

\section{DATA ANALYSIS}

Table1.1: CAMEL Ratio of Ellaqui Dehati Bank

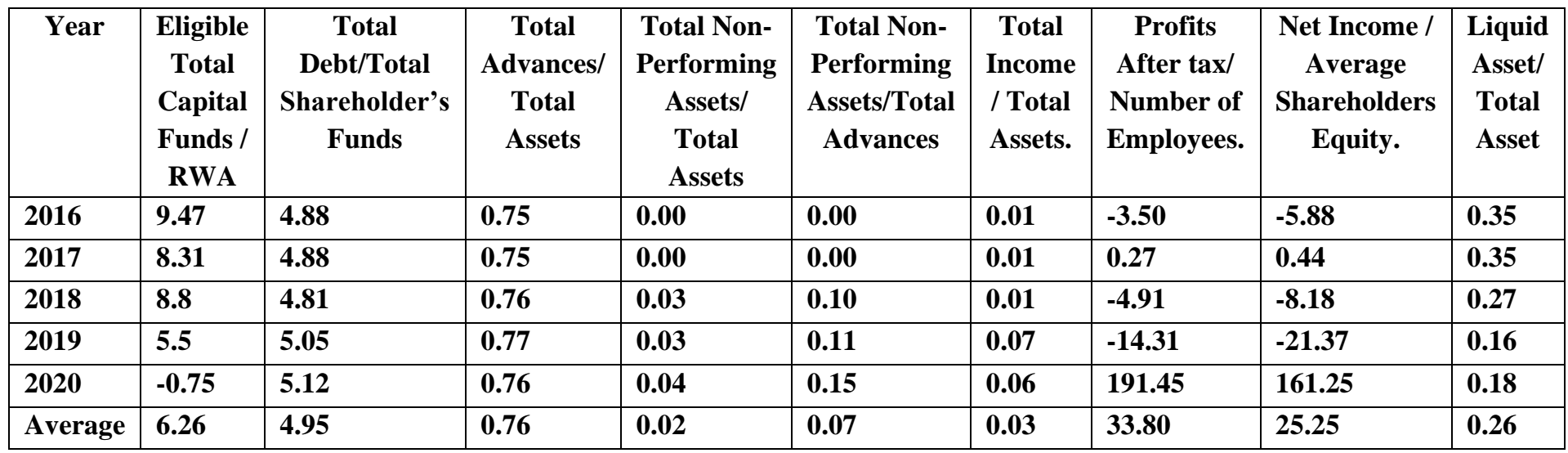

Source: Data extracted from Annual Financial Reports.

In the above table, we can observe that in terms of capital adequacy the EDB has performed well except for the year 2020. In terms of asset quality, the bank has not performed well and total advances to total assets have not shown any change but there is a gradual increase in NPS's so, the management has not been efficient enough. The bank has not performed well in terms of earnings quality and liquidity as well.

Table 1.2: CAMEL Ratio of J\&K Grameen Bank

\begin{tabular}{|c|c|c|c|c|c|c|c|c|c|}
\hline Year & $\begin{array}{l}\text { Eligible } \\
\text { Total } \\
\text { Capital } \\
\text { Funds / } \\
\text { RWA }\end{array}$ & $\begin{array}{l}\text { Total } \\
\text { Debt/Total } \\
\text { Shareholder's } \\
\text { Funds }\end{array}$ & $\begin{array}{l}\text { Total } \\
\text { Advances/ } \\
\text { Total } \\
\text { Assets }\end{array}$ & $\begin{array}{l}\text { Total Non- } \\
\text { Performing } \\
\text { Assets/ } \\
\text { Total } \\
\text { Assets }\end{array}$ & $\begin{array}{l}\text { Total Non- } \\
\text { Performing } \\
\text { Assets/Total } \\
\text { Advances }\end{array}$ & $\begin{array}{l}\text { Total } \\
\text { Income } \\
\text { / Total } \\
\text { Assets. }\end{array}$ & $\begin{array}{l}\text { Profits } \\
\text { After tax/ } \\
\text { Number of } \\
\text { Employees. }\end{array}$ & $\begin{array}{l}\text { Net Income / } \\
\text { Average } \\
\text { Shareholders } \\
\text { Equity. }\end{array}$ & $\begin{array}{l}\text { Liquid } \\
\text { Asset/ } \\
\text { Total } \\
\text { Asset }\end{array}$ \\
\hline 2016 & 0.103 & 1.54 & 0.00 & 0.492 & 0.000 & 0.089 & 70.01 & 1.74 & 0.5 \\
\hline 2017 & 0.166 & 1.42 & 0.36 & 0.274 & 0.763 & 0.083 & -290.54 & 1.82 & 0.4 \\
\hline 2018 & 0.104 & 1.42 & 0.39 & 0.420 & 1.071 & 0.083 & 293.82 & 1.90 & 0.4 \\
\hline 2019 & 0.172 & 1.47 & 0.42 & 0.240 & 0.571 & 0.079 & 161.20 & 1.92 & 0.4 \\
\hline 2020 & 0.145 & 0.96 & 0.45 & 0.262 & 0.584 & 0.081 & -1956.37 & 2.14 & 0.3 \\
\hline Average & 0.138 & 1.36 & 0.32 & 0.338 & 0.598 & 0.083 & -344.38 & 1.91 & 0.4 \\
\hline
\end{tabular}

Source: Data extracted from Annual Financial Reports. 
In the table above we can observe that J\&K Grameen Bank has not performed well in terms of capital adequacy. The asset quality of the bank has also not been good as per the ratios. The management also has not efficient enough and we can see an increase in NPA's. Bank has shown losses for many years during the period of the study reveals the poor quality of earnings. In terms of liquidity also the numbers are not impressive.

\section{Hypothesis:}

To compare the financial performance of these two selected banks, a hypothesis is framed, which will be tested using ANOVA in SPSS.

H0: The financial performance of J\&K Grameen Bank(JKGB) and Ellaqui Dehati Bank(EDB) does not differ.

\begin{tabular}{lr|r|r|r|r}
\multicolumn{7}{c}{ ANOVA } \\
Camels Ratios & Sum of Squares & df & Mean Square & F & Sig. \\
\hline Between Groups & 9367.748 & 1 & 9367.748 & 1.400 & .254 \\
\hline Within Groups & 107095.188 & 16 & 6693.449 & & \\
\hline Total & 116462.935 & & 17 & & \\
\hline
\end{tabular}

In the output above, we can see that there is no significant difference between the financial performance of EDB \& JK Grameen bank because the p-value is 0.254 , which is more than the common Alpha level of 0.05 ; this indicates that it is statistically not significant.

\section{FINDINGS AND CONCLUSION}

he financial performance of EDB in terms of capital adequacy is good except for the year 2020 . The bank has also performed well in terms of asset quality, but the bank has not performed well and total advances to total assets have not shown any change but there is a gradual increase in NPS's which means the management has not been efficient enough to tackle the nonperforming assets. The bank has not performed well in terms of earnings quality and liquidity as well, there will be a risk of liquidity crisis if the bank does not improve its liquidity. On the other hand, J\&K Grameen Bank has not performed well in terms of capital adequacy. The asset quality of the bank has also not been good as per the results. The management also has not efficient enough and we can see an increase in NPA's, so the bank has to manage the nonperforming assets before it is too late. Bank has shown losses for many years during the period of the study shows the poor quality of earnings. In terms of liquidity also the numbers are not impressive, so this bank also may go into a liquidity crisis if proper steps are not taken.

Ellaqui Dehati Bank and JK Grameen bank are two important financial institutions that serve the rural population of Jammu and Kashmir. These banks have played an important role in financial inclusion. But as per the results, both these institutes have not performed well. There is also no significant difference between their financial performances as both these banks serve similar kinds of customers who are of equal economic status. There is a need for these institutions to improve their financial performance so that they do not become a burden on the government. 


\section{References:}

1. Selvakumar, S., \& Abima, D. (2020). Appraisal of Financial Performance of Regional Rural Banks with Special Reference to Assam Gramin Vikash Bank, Maharashtra Gramin Vikash Bank and Karnataka Gramin Vikash Bank. International Journal of Research in Engineering, Science and Management, 3(12), 191-196.

2. Kumar, M., Jegatheesan, S. K., \& Aruna, G. (2013). A performance evaluation of regional rural banks in India. The Indian Journal of Commerce, 66.

3. Adam, M. H. M. (2014). Evaluating the Financial Performance of Banks using financial ratios-A case study of Erbil Bank for Investment and Finance. European Journal of Accounting Auditing and Finance Research, 2(6), 162-177.

4. Ahmeti, S., Hoti, A., \& Alshiqi, S. (2014). Analysis of Financial Performance in the Banking System in Kosovo-the Period 2006-2012. Journal of Knowledge Management, Economics and Information Technology, IV, 2(2).

5. Rauf, A. L. (2016). Towards Increasing the financial performance: An application of CAMEL Model in banking sector in the context of Sri Lanka. Research Journal of Finance and Accounting, 7(5), 66-71.

6. Kanika, N., \& Sahni, N. (2013). Financial performance evaluation of RRB's in india. International Journal of Management \& Information Technology, 4(2). Kumar, S., \& Sharma, R. (2014). Performance analysis of top Indian banks through CAMEL approach. International Journal of Advanced Research in Management and Social Sciences, 3(7), 81-92.

7. Majumder, M., Hossain, T., \& Rahman, M. M. (2017). A camel model analysis of selected banks in Bangladesh. Mohammed Mizanur, A CAMEL Model Analysis of Selected Banks in Bangladesh (November 9, 2017).

8. Soni, A. K., \& Kapre, A. (2012). Performance Evaluation of the Regional Rural Banks in India. National Monthly Refereed Journal of Research In.

9. Kumar, S., \& Sharma, R. (2014). Performance analysis of top Indian banks through CAMEL approach. International Journal of Advanced Research in Management and Social Sciences, 3(7), 81-92.

10. Kumar, M., Jegatheesan, S. K., \& Aruna, G. (2013). A performance evaluation of regional rural banks in India. The Indian Journal of Commerce, 66. 